\title{
Study on the Linkage between Between International Crude Oil Price and Sino-U.S. Stock Market against Against the Backdrop of Trade War
}

\author{
Jian Jie \\ University of Macau, Macau, 999078, China \\ sb62324@um.edu.mo
}

keywords: Trade War; International Crude Oil Prices; Sino-U.S. Stock Markets

\begin{abstract}
The U.S.-China trade war is increasingly having a significant impact on financial markets and the world economy. Based on the daily data from 2017 to June 2019, this paper carries out an empirical study on the mean spillover effect and volatility spillover effect of international crude oil prices and Sino-U.S. stock markets by adopting VAR model and multivariate BEKK-GARCH model. The results show that in terms of mean spillover effect, the trade war has not changed the linkage between Sino-U.S. stock markets and there is no notable spillover effect between international crude oil prices and Sino-U.S. stock markets. While in terms of volatility spillover effect, the impact of the trade war is evident in the risk contagion between international crude oil markets and Sino-U.S. stock markets. The volatility spillover effect between the international crude oil markets and the U.S. stock market is enhanced, while the volatility spillover effect between the Chinese stock markets is weakened. In addition, the risk contagion effect between Sino-U.S. stock markets has also undergone changes in varying degrees.
\end{abstract}

\section{Introduction}

With the U.S. government's announcement of extra tariffs on $\$ 50$ billion of Chinese exports on March 22, 2018, the Sino-U.S. trade war is increasingly gaining momentum in the seesaw struggle. This trend has produced far-reaching influence on global economic and financial markets. Finance is a keen barometer of the economy. The trade war not only plays a role in the economic development of China and the United States, but also exerts influence on the international commodity markets, which perform an indispensible task for financial market. Therefore, the trade war may not only change the linkage between the financial markets of the two countries, but also may effect a change in the relationship between the international commodity markets and the Sino-U.S. stock markets. As a result, research on the linkage between the international crude oil markets and the Sino-U.S. stock markets during the trade war not only helps to explore changes of relationship between different financial markets in further escalation of the trade war, but also provides theoretical and practical guidance to the risk management of transmission between financial markets at home and abroad. For this reason, the research conducted in this paper has much practical significance.

\section{Literature Review}

Developed countries and regions play a leading role in the global financial markets. Therefore, most of the research on the linkage of financial markets takes developed countries or regions as samples. Hamao et al. (1990) made an earlier empirical analysis of the spillover effect between the stock markets of the U.S., the U.K. and Japan. The results show that before 1987, there existed one-way price fluctuation transmission from the United States to Japan, from the United Kingdom to Japan and from the United States to the United Kingdom. Jang and Sul (2002) conducted an empirical analysis of the causal effect between the major Asian financial markets after the financial crisis. The results have proved the validity of the significant impact that the financial crisis had on the linkage between financial markets in different countries or regions. Before the crisis, the spillover effect between financial markets was less remarkable; however, the Japan-dominated financial market has generated more spillover effects after the global financial crisis. Albuquerque et al. (2006) explored 
the impact of financial markets in developed countries on financial markets in Latin America. It turned out that only American financial markets had a significant impact on Mexican financial markets, while neither American nor European financial markets exerted such influence on financial markets in Chile or Brazil.

In the context of linkage research between international commodity markets and financial markets, Hillier et al. (2006) found that there is a weak correlation between the price of gold, silver and platinum and stock index return rates. As a result, international commodities can be chosen as a portfolio. Arouri et al. (2012) empirically studied the spillover effects between crude oil prices and European stock markets based on the VAR-GARCH model. The results show that there is a noticeable volatility spillover effect between the two objects. Ratti and Hasan (2013) also confirmed this phenomenon through their research on Australia. Based on the research of financial markets in eight developed countries, Dhaoui and Khraief (2014) found that there is a significant negative correlation between crude oil prices and stock market indices with the exception of Singapore.

A review of the existing literature reveals that there is a spillover effect between different international financial markets, which is affected by major international events. As we all know, the trade war initiated by the United States is making great difference to the world economy and financial markets. Will this incident affect the relationship between international commodity markets and financial markets? Based on research gaps in the existing literature, this paper takes the trade war as the starting point and probes into the linkage between international crude oil prices and the Sino-U.S. stock markets.

\section{Model selection and data description}

\subsection{Model selection}

In the analysis of financial time series, it is necessary to consider the mean spillover effect and the volatility spillover effect between different sequences. The VAR model is preferred in order to test the mean spillover effect. The VAR model can be used to identify whether there is a causal relationship between different sequences. The multivariate BEKK-GARCH model proposed by Engle and Kroner (1995) is favored by researchers when testing the volatility spillover effect. Based on this, this paper adopts the VAR model and the multivariate BEKK-GARCH model to empirically test the mean spillover effect and the volatility spillover effect between the international crude oil prices and the Sino-U.S. stock markets.

\subsection{Data description}

This paper selects the daily data from 2017 to June 2019 as the analytical focus. The Standard \& Poor's 500 Index (sp) and the Shanghai Composite Index (sse) are collected from the Yahoo Finance website at https://finance.yahoo.com. WTI crude oil futures price (wti) data comes from the U.S. National Energy Agency at https://www.eia.gov. It first takes the logarithm of the original data, and then implements the first-order difference to obtain the return series. The specific calculation formula is as follows:

$$
d \ln p_{t}=\ln p_{t}-\ln p_{t-1}
$$

Among them, $p_{t}$ stands for price series, $d$ represents the first-order difference operator, $\ln$ is the natural logarithm and $d \ln p_{t}$ represents the price returns series.

Descriptive statistics of indicators after logarithmization are shown in Table 1.

Table 1 Descriptive Statistics of Variables

\begin{tabular}{ccccccccc}
\hline variable & Mean & Std & Max & Min & Skew & Kurt & J-B & P-value \\
\hline$d \ln s p$ & 0.0005 & 0.0084 & 0.0484 & -0.0418 & -0.5872 & 8.4087 & 737.76 & 0.0000 \\
$d \ln s s e$ & -0.0001 & 0.0110 & 0.0545 & -0.0601 & -0.4852 & 7.7153 & 558.16 & 0.0000 \\
$d \ln w t i$ & 0.0002 & 0.0185 & 0.0832 & -0.0802 & -0.7244 & 6.4742 & 197.98 & 0.0000 \\
\hline
\end{tabular}


It can be seen from Table 1 that during the research period, the logarithmic rate of return of the Standard \& Poor's 500 Index is positive, while the logarithmic rate of return of the Shanghai Composite Index is negative, and the logarithmic rate of return of the WTI crude oil futures is positive. The skewness of the three return series is negative, that is, the return series are in left-skewed distribution. In addition, the kurtosis of the three return series is considerably greater than 3; the value of the Jarque-Bera statistic (JB) used to test the sequence normality is larger; the corresponding probability is less than 0.01 , which indicates that at the level of $1 \%$, the three return series are in non-normal distributions of high peaks and heavy tails. Thus, the return series constructed in this paper can be used for variability modeling between sequences.

\section{Empirical analysis}

The spillover effect between financial market prices is divided into two aspects: horizontal price spillover and volatility spillover. Therefore, this paper conducts an empirical analysis on the two aspects of mean spillover effect and volatility spillover effect testing. At the same time, in order to reflect the possible impact of Sino-U.S. trade war on empirical results, this paper takes March 22, 2018 as the beginning of the trade war, which is regarded as a time-dividing point to empirically study the impact of international crude oil prices on Sino-U.S. financial markets before and after the trade war.

\subsection{Mean overflow effect testing}

With the assistance of the VAR model, the estimation and test results of the horizontal price spillover effect between the international crude oil price markets and the Sino-U.S. stock markets are shown in Table 2.

Table 2 Mean overflow effect estimation and testing results

\begin{tabular}{|c|c|c|c|c|c|c|}
\hline \multirow[t]{2}{*}{ variable } & \multicolumn{3}{|c|}{$\begin{array}{l}\text { Before the Trade War } \\
(2017.1 .3-2018.3 .22)\end{array}$} & \multicolumn{3}{|c|}{$\begin{array}{l}\text { During the Trade War } \\
(2018.3 .23-2019.6 .28)\end{array}$} \\
\hline & $d \ln s p$ & $d \ln s s e$ & $d \ln w t i$ & $d \ln s p$ & $d \ln s s e$ & $d \ln w t i$ \\
\hline$d \ln s p_{t-1}$ & $\begin{array}{l}-0.0445 \\
(0.0616)\end{array}$ & $\begin{array}{l}0.2908^{* * *} \\
(0.0690)\end{array}$ & $\begin{array}{c}0.1037 \\
(0.1667)\end{array}$ & $\begin{array}{c}-0.0850 \\
(0.0566)\end{array}$ & $\begin{array}{l}0.3048^{* * *} \\
(0.0799)\end{array}$ & $\begin{array}{c}0.0423 \\
(0.1223)\end{array}$ \\
\hline$d \ln s s e_{t-1}$ & $\begin{array}{l}-0.0832^{* *} \\
(0.0417)\end{array}$ & $\begin{array}{l}-0.0241 \\
(0.0574)\end{array}$ & $\begin{array}{c}0.1217 \\
(0.1426)\end{array}$ & $\begin{array}{l}-0.0558^{*} \\
(0.0329)\end{array}$ & $\begin{array}{l}-0.0864 \\
(0.0570)\end{array}$ & $\begin{array}{l}-0.0822 \\
(0.0710)\end{array}$ \\
\hline$d \ln w t i_{t-1}$ & $\begin{array}{c}0.0016 \\
(0.0187)\end{array}$ & $\begin{array}{c}0.0284 \\
(0.0209)\end{array}$ & $\begin{array}{l}-0.0076 \\
(0.0642)\end{array}$ & $\begin{array}{l}-0.0042 \\
(0.0225)\end{array}$ & $\begin{array}{l}-0.0022 \\
(0.0418)\end{array}$ & $\begin{array}{l}-0.0961^{*} \\
(0.0578)\end{array}$ \\
\hline constant & $\begin{array}{l}0.0010^{* * *} \\
(0.0003)\end{array}$ & $\begin{array}{c}0.0001 \\
(0.0003) \\
\end{array}$ & $\begin{array}{c}0.0007 \\
(0.0005) \\
\end{array}$ & $\begin{array}{l}0.0011^{* * *} \\
(0.0004)\end{array}$ & $\begin{array}{c}0.0002 \\
(0.0008) \\
\end{array}$ & $\begin{array}{c}0.0007 \\
(0.0010) \\
\end{array}$ \\
\hline \multicolumn{7}{|c|}{ Mean overflow effect testing } \\
\hline$d \ln s p \rightarrow$ & - & $\begin{array}{c}17.7460 * * * \\
{[0.0000]}\end{array}$ & $\begin{array}{c}0.3866 \\
{[0.5341]}\end{array}$ & - & $\begin{array}{c}14.544 * * * \\
{[0.0001]}\end{array}$ & $\begin{array}{c}0.1194 \\
{[0.7296]}\end{array}$ \\
\hline$d \ln s s e \rightarrow$ & $\begin{array}{c}3.9909 * * \\
{[0.0457]}\end{array}$ & - & $\begin{array}{c}0.7290 \\
{[0.3932]}\end{array}$ & $\begin{array}{c}2.8802^{*} \\
{[0.0897]}\end{array}$ & L & $\begin{array}{c}1.3415 \\
{[0.2468]}\end{array}$ \\
\hline$d \ln w t i \rightarrow$ & $\begin{array}{c}0.0077 \\
{[0.9299]}\end{array}$ & $\begin{array}{c}1.8426 \\
{[0.1746]}\end{array}$ & - - & $\begin{array}{c}0.0342 \\
{[0.8533]}\end{array}$ & $\begin{array}{c}0.0028 \\
{[0.9575]}\end{array}$ & - \\
\hline
\end{tabular}

As seen in Table 2, the influence coefficient of $d \ln$ sse on $d \ln s p$ was -0.0832 before the trade war, and it was significant at the level of 5\%. The influence coefficient of $d \ln s p$ on $d \ln s s e$ was 0.2908 , and it was significant at the level of 1\%, which indicates that the Standard \& Poor's 500 Index will change accordingly with the Shanghai Composite Index and the two indexes correlate with each other. The mean spillover effect testing shows that the Shanghai Composite Index and the Standard \& Poor's 500 Index are mutually seen as Granger causes, that is, a causal relationship exists between them. It means that there is a strong interaction between the financial markets of China and the United States. However, the influence coefficient of $d \ln w t i$ on $d \ln s p$ and $d \ln$ sse is not symbolic, and the testing results of the mean spillover effect also confirm that the WTI crude oil futures price is not the Granger reason for the changes in the Shanghai Composite 
Index and the S\&P 500 Index.

The estimated results of post trade war show that the influence coefficient of $d \ln s s e$ on $d \ln s p$ becomes -0.0558 , which is significant at the $10 \%$ level. Compared with the pre-war situation, the absolute value of estimated coefficient becomes smaller and the significance is decreased. However, the mean spillover effect testing also indicates that the two are mutually considered as Granger causes and the trade war has not changed the mean spillover effect between the financial markets of China and the United States. In addition, the impact of $d \ln w t i$ on $d \ln s p$ and $d \ln s s e$ is still not significant and there is no causal relationship between WTI crude oil price and the two indexes.

\subsection{Volatility spillover effect testing}

The results of the mean spillover effect only projects that a horizontal price spillover exists between the stock markets of China and the United States, while there is no causal relationship between the international crude oil futures price and the stock markets of China and the United States. However, a significant volatility normally present in the financial price series, while greater volatility represents greater risk. Therefore, with the deepening of international financial market integration, is there any risk contagion between the international crude oil markets and the stock markets? In order to answer this question, this paper makes use of the multivariate BEKK-GARCH model to empirically analyze the volatility spillover effect between the international crude oil markets and the Sino-U.S. financial markets. At the same time, in order to further reflect the impact of trade war on risk contagion, this paper has estimated the relevant situations before and after the trade war. The specific results are shown in Table 3.

Table 3. BEKK-GARCH model estimation results

\begin{tabular}{|c|c|c|c|c|c|c|}
\hline \multirow[t]{2}{*}{ variable } & \multicolumn{3}{|c|}{$\begin{array}{l}\text { Before the Trade War } \\
(2017.1 .3-2018.3 .22)\end{array}$} & \multicolumn{3}{|c|}{$\begin{array}{l}\text { During the Trade War } \\
(2018.3 .23-2019.6 .28)\end{array}$} \\
\hline & $\begin{array}{c}d \ln s p \\
j=1\end{array}$ & $\begin{array}{c}d \ln s s e \\
j=2\end{array}$ & $\begin{array}{c}d \ln w t i \\
j=3\end{array}$ & $\begin{array}{c}d \ln s p \\
j=1\end{array}$ & $\begin{array}{c}d \ln s s e \\
j=2\end{array}$ & $\begin{array}{c}d \ln w t i \\
j=3\end{array}$ \\
\hline $\mathrm{c}_{1 \mathrm{j}}$ & $\begin{array}{l}-0.0006 \\
(0.0005)\end{array}$ & & & $\begin{array}{l}0.0012 * \\
(0.0007)\end{array}$ & & \\
\hline$c_{2 j}$ & $\begin{array}{l}-0.0015 \\
(0.0029)\end{array}$ & $\begin{array}{l}-0.0001 \\
(0.0033)\end{array}$ & & $\begin{array}{c}0.0107 * * * \\
(0.0021)\end{array}$ & $\begin{array}{c}0.0073 * * * \\
(0.0023)\end{array}$ & \\
\hline$c_{3 j}$ & $\begin{array}{c}0.0140 * * * \\
(0.0028)\end{array}$ & $\begin{array}{c}0.0010 \\
(0.0151)\end{array}$ & $\begin{array}{l}-0.0002 \\
(0.0261)\end{array}$ & $\begin{array}{c}0.0053 * * * \\
(0.0015)\end{array}$ & $\begin{array}{l}-0.0014 \\
(0.0009)\end{array}$ & $\begin{array}{c}-1.28 \mathrm{e}-07 \\
(0.0066)\end{array}$ \\
\hline$a_{1 j}$ & $\begin{array}{c}0.3977 * * * \\
(0.0743)\end{array}$ & $\begin{array}{c}-0.3534 * * * \\
(0.0923)\end{array}$ & $\begin{array}{l}-0.0312 \\
(0.1624)\end{array}$ & $\begin{array}{c}0.3461 * * * \\
(0.0587)\end{array}$ & $\begin{array}{l}0.3054 * * \\
(0.1228)\end{array}$ & $\begin{array}{c}0.0481 \\
(0.1820)\end{array}$ \\
\hline$a_{2 j}$ & $\begin{array}{c}0.0755 \\
(0.0755)\end{array}$ & $\begin{array}{l}0.1891 * \\
(0.0991)\end{array}$ & $\begin{array}{l}-0.2592 \\
(0.2216)\end{array}$ & $\begin{array}{c}0.0992 * * * \\
(0.0248)\end{array}$ & $\begin{array}{l}-0.1196 \\
(0.1376)\end{array}$ & $\begin{array}{c}0.0552 \\
(0.0773)\end{array}$ \\
\hline$a_{3 j}$ & $\begin{array}{l}-0.0017 \\
(0.0229)\end{array}$ & $\begin{array}{c}0.0694 \\
(0.0429)\end{array}$ & $\begin{array}{l}-0.0673 \\
(0.0919)\end{array}$ & $\begin{array}{c}0.0072 \\
(0.0294)\end{array}$ & $\begin{array}{c}-0.1454 * * \\
(0.0724)\end{array}$ & $\begin{array}{c}0.1909 * * * \\
(0.0632)\end{array}$ \\
\hline$b_{1 j}$ & $\begin{array}{c}0.7799 * * * \\
(0.1018)\end{array}$ & $\begin{array}{c}0.5320 * * * \\
(0.1469)\end{array}$ & $\begin{array}{l}1.0037 * * \\
(0.5020)\end{array}$ & $\begin{array}{c}0.8688 * * * \\
(0.0541)\end{array}$ & $\begin{array}{c}0.1117 \\
(0.1688)\end{array}$ & $\begin{array}{c}1.4114 * * * \\
(0.0512)\end{array}$ \\
\hline $\mathrm{b}_{2 \mathrm{j}}$ & $\begin{array}{c}0.3025 * * \\
(0.1248)\end{array}$ & $\begin{array}{l}-0.0225 \\
(0.1673)\end{array}$ & $\begin{array}{c}0.1740 \\
(0.3688)\end{array}$ & $\begin{array}{c}0.0329 \\
(0.0973)\end{array}$ & $\begin{array}{c}0.0095 \\
(0.4918)\end{array}$ & $\begin{array}{l}-0.1976 \\
(0.3949)\end{array}$ \\
\hline$b_{3 j}$ & $\begin{array}{c}0.0663 \\
(0.0657) \\
\end{array}$ & $\begin{array}{c}-0.3097 * * * \\
(0.0655)\end{array}$ & $\begin{array}{c}-0.2328 \\
(-0.4535) \\
\end{array}$ & $\begin{array}{c}-0.2697 * * * \\
(0.0135)\end{array}$ & $\begin{array}{l}-0.0288 \\
(0.0645)\end{array}$ & $\begin{array}{c}0.5628 * * * \\
(0.0119)\end{array}$ \\
\hline \multicolumn{7}{|c|}{ Volatility spillover effect testing } \\
\hline$j=1 \longrightarrow$ & - & $\begin{array}{c}55.1756^{* * *} \\
{[0.0000]}\end{array}$ & $\begin{array}{l}4.6787^{*} \\
{[0.0964]}\end{array}$ & - & $\begin{array}{l}7.3854 * * \\
{[0.0249]}\end{array}$ & $\begin{array}{c}903.098^{* * *} \\
{[0.0000]}\end{array}$ \\
\hline$j=2 \longrightarrow$ & $\begin{array}{c}10.8628 * * * \\
{[0.0044]}\end{array}$ & - & $\begin{array}{c}1.7099 \\
{[0.4253]}\end{array}$ & $\begin{array}{c}16.5390 * * * \\
{[0.0003]}\end{array}$ & - & $\begin{array}{c}1.0967 \\
{[0.5779]}\end{array}$ \\
\hline$j=3 \longrightarrow$ & $\begin{array}{c}1.0458 \\
{[0.5928]}\end{array}$ & $\begin{array}{c}25.9761 * * * \\
{[0.0000]}\end{array}$ & - - & $\begin{array}{c}405.917 * * * \\
{[0.0000]}\end{array}$ & $\begin{array}{c}4.1248 \\
{[0.1271]}\end{array}$ & - \\
\hline
\end{tabular}

Seeing from the estimation and testing results in Table 3, there is a volatility spillover effect of $d \ln s p$ on both $d \ln s s e$ and $d \ln w t i$ before the trade war, which indicates that U.S. stocks show risk transmission towards the Chinese stock markets and the international crude oil markets. A 
volatility spillover of $d \ln s s e$ works only on $d \ln s p$, and there is no significant volatility spillover on $d \ln w t i$. This phenomenon means that the Chinese stock markets only generate risk contagion to the U.S. stock markets but do not transmit the risk to the international crude oil markets. There is a great volatility spillover of $d \ln w t i$ on $d \ln s s e$, which indicates that the international crude oil markets can only spread risks towards the Chinese financial markets, and no risk is transferred to the U.S. financial markets.

The estimated results of the trade war show that the volatility spillover effect of $d \ln s p$ on $d \ln s s e$ and $d \ln w t i$ is still significant, while the volatility spillover effect on $d \ln w t i$ is obviously enhanced. There has been no substantial changes in the volatility spillover effect of $d \ln s s e$ on $d \ln s p$ and $d \ln w t i$. The volatility spillover effect of $d \ln w t i$ is no longer noticeable, but that of $d \ln s p$ shows stronger influence. The empirical results demonstrate that the trade war has changed the risk contagion effect between the U.S. stock markets and the international crude oil markets. The linkage between the U.S. stock markets and the international crude oil markets is increasingly intensified, and the risk transmission mechanism between the Sino-U.S. stock markets has not changed in a dramatic way. The risk linkage between the international crude oil markets and the Chinese stock markets has gradually faded away.

\section{Conclusion}

There is a growing impact of the U.S.-sponsored trade war on the global economy and finance. Would the important part of the international commodity markets affect Sino-U.S. finance with the emergence of trade war? To investigate that, this paper collects the daily data from 2017 to June 2019 and adopts VAR model and multivariate BEKK-GARCH model to empirically analyze the linkage between international crude oil prices and Sino-U.S. stock markets. The results show that there is a significant mean spillover effect between Chinese and American stock markets. But the mean spillover effect of the Chinese stock markets on the American stock markets tends to weaken after the trade war. In addition, neither the international crude oil markets nor the Sino-U.S. stock markets have shown mean spillover effects between them. In terms of the risk contagion between financial markets, the trade war has increased the volatility spillover between the U.S. stock markets and the international crude oil markets. China's risk contagion to the American stock markets has also demonstrated a steady growth. Moreover, the trade war has weakened the volatility spillover effect of the United States on Chinese stock markets and international crude oil markets.

\section{References}

[1] Y. Hamao, R.W. Masulis and V. Ng, Correlations in Price Changes and Volatility across International Stock Markets, Review of Financial Studies,1990, 3(2):281-307.

[2] H. Jang and W. Sul, The Asian financial crisis and the co-movement of Asian stock markets, Journal of Asian Economics, 2002, 13(1):94-104.

[3] P. H. Albuquerque, A. Rivas and Rodríguez A.. Are European Stock Markets Influencing Latin American Stock Markets?, Análisis Económico, 2006, 21(47):51-67.

[4] D. Hillier, P. Draper and R. Faff, Do Precious Metals Shine? An Investment Perspective, Financial Analysts Journal, 2006, 62(2): 98-106.

[5] M. E. H. Arouri, J. Jouini and D. K. Nguyen, On the impacts of oil price fluctuations on European equity markets: Volatility spillover and hedging effectiveness, Energy Economics, 2012, 34(2):611-617.

[6] R.A. Ratti and M.Z. Hasan, Oil Price Shocks and Volatility in Australian Stock Returns, Economic Record, 2013, 89(S1):67-83.

[7] A. Dhaoui and N. Khraief, Empirical Linkage between Oil Price and Stock Market Returns and 
Volatility: Evidence from International Developed Markets, Economics Discussion Papers, 2014-12,2014.

[8] R.F. Engle and F. Kroner, Multivariate Simultaneous Generalized ARCH, Econometric Theory, 1995,11(1):122-150. 